\title{
TAXONOMIC STUDY FOR THE NEW RECORD EPILOBIUM OBSCURUM SCHREBER (ONAGRACEAE) IN IRAQ
}

\author{
Abdullah Sh. Sardar \\ Department of Biology, College of Education, University of Salahaddin- \\ Erbil, Erbil, Iraq Aborosa1972@yahoo.com
}
Aboothar Ha.Al-Edhari.
Department of Ecology, College of Sciences, University of Kufa, Najaf, Iraq abothar.alathari@uokufa.edu.iq

ORCID ID: $\underline{0000-0002-5794-1536}$

\section{Crossref http://dx.doi.org/10.26739/2433-202x \\ Issue DOI http:/ / dx.doi.org/10.26739/2433-202x-2017-6-6 \\ Article DOI http://dx.doi.org/10.26739/2433-202x-2017-6-6-8}

\begin{abstract}
Epilobium obscurum Schreber is a new additional plant species to Onagraceae family in Iraq, present in Qandil mountain (north-east of Erbil) of Rowanduz district (MRO). The identification of the species was confirmed by using keys in the available references, morphological description was done, and some distinguishing characters are given. Some pollen grains characters have been studied such as shapes, colors, sizes and numbers. In addition, some features of the leaf venation; as well as stomatal complex characters of the leaf have been studied.
\end{abstract}

Key words: Epilobium obscurum, Onagraceae, Rowandus district, Iraq. 


\section{1- Introduction}

From the families in the Flora of Iraq is Onagraceae which involves 650 species throughout the world and distributed on 24 genera [1], in Iraq contain 9 species distributed on 2 genera [2].

In the Flora of U.S.S.R., [3] pointed to 51 species of the genus Epilobium Spach involving E. obscurum. [4] in Saudi Arabia mentioned 1 species which is E. hirsutum L., while [5] stated 10 species in Syria, Palestine and Sinai. [6] in Turkey indicated 21 species of the genus involving E. obscurum. In Europe, [7] stated 27 species of the genus Epilobium involving E. obscurum. In Iran, [8] mentioned that 29 species of the genus found, while [9] stated 19 species. In the Flora of low land Iraq, [10] pointed to 1 species which is E. hirsutum. Each of [11, 12 and 13] stated that 4 species of the genus found in Iraq, but [2] mentioned 6 species and [14] indicated 7 species, while [15] mentioned 5 species. Each of [16, 17, 18, 19 and 20] did not mention any species of the genus Epilobium in Piramagrun, Haibat Sultan, Gomaspan, Choman and Hujran respectively. [21] mentioned 1 species in Sinjar mountain, while [22] stated 4 species in Hawraman mountains. [23] stated that the species E. hirsutum which present in Iraq is reported to be poisonous, causing epileptiform convulsions. The plantjuice is reported to be used as an application for warts in certain parts of South Africa. [24] mentioned that the genera Epilobium, Jussiaea, and Ludwigia regarded as aquatic plants of Iraq within the family Onagraceae. The studies of [25, 26 and 27] are similar works with the present study that involves new plant records in Iraq.

The present work assured the presence of E. obscurum in Iraq based on recent collection, as well as morphological characters, pollen grains with leaf venation and stomatal complex characters, to added extra information for supporting the identity of the species under study.

\section{2- Materials and Methods}

For plant specimen's collection, field trips in different regions of northern districts of Iraq have been done in 2016. By using the keys especially in Flora of Iraq, Flora of Turkey and Flora Iranica, the specimens have been identified, then treated and preserved in herbarium of Education College (ESUH). Some ecological notes and the presence location as shown in the map (Figure 1) have been given. For the pollen 
grains, anthers were fixed in FAA, and then a single anther removed and placed in a drop of water or $50 \%$ glycerol (the latter to prevent the material from drying out). The anther was dissected with a scalpel to extrude the pollen grains. The anther wall material was removed after crushing pollen grains. In addition, a drop of safranin was added and then a cover-slip was slided on top of the pollen. [1]. For the leaf venation, the procedure in [28] has been followed. A Sony camera has been used for photographing the different plant parts and the scientific terms that used in the study have been taken from 29, 30, 31 and 32]. For the stomatal complex, the procedure in [33] has been used and the information in [34 and 35] were utilized.

\section{3- Results}

E. obscurum Schreber, Spic. 147, 155 (1771). Ic: Ross-Craig, Draw. Brit. PI. 11: t. 25 (1958); Fl. Europaea, Raven, 2: 310 (1968); Fl. Turkey, Chamberlain and Raven, 4: 190 (1972).

Perennial, herb, perennating by elongate epigeal stolons, height 23$45 \mathrm{~cm}$, stem erect or ascending, 4-costate, glabrous below, adpressed crisped hairy above, green-yellow, 8-20x0.1-0.15 cm. Leaves simple, sessile, exstipulate, opposite-decussate in the lower half, alternate-spiral in the upper half, enlarge upwardly, margin entire or dentate-serrate, apex obtuse or acute, base truncate rounded or cuneate, decurrent glabrous; basal leaves narrowly ovate, oblong, green or dark brown, 5-9x2.5-4.0 mm; lower cauline leaves elliptic, elliptic-oblong, green, 7.5-13.0×3.0-6.0 mm; upper cauline leaves narrowly ovate, lanceolate, densely crisped margins and veins, green, 7-26×2-13 mm. Bracts narrowly elliptic, margin entirecrenate, apex acute, base obtuse, densely crisped margins and veins, green, 1.5-2.0x0.4-0.6 mm.

Flowers solitary and axillary, actinomorphic, 4-merous, 16.8-24.7x3$5 \mathrm{~mm}$, pedicel teret, crisped-glandular, green, 1.5-3.0x0.5-0.7 mm, Calyx of 4 sepals, free, triangular, margin entire-crenate, apex acute, base truncate, crisped-glandular, rose or rose-green, 3-4x0.8-1.2 mm. Corolla of 4 petals, narrowly obovate, margin entire, apex emarginate, base truncate, rosepurple, 3.5-6.5x1.5-3.0 mm, Stamens 8, in two whorls, 4 long antisepalous, 4 shorter antipetalous; filaments filiform, yellow, long ones 2.0-3.2x0.12$0.15 \mathrm{~mm}$, short ones 1.0-1.2x0.10-0.12 mm; anthers oblong, yellow, basifixed attechment with the filaments, $0.8-1.2 \times 0.4-0.6 \mathrm{~mm}$. Pistil 1, ovary inferior, cylindrical, 4-locular, 4-furrow and ridge, crisped-glandular, 
yellow, 12-19x0.6-1.3 mm; style single, filiform, yellow, 3-5x0.20-0.35 mm; stigma entire-clavate, yellow, 0.7-1.1 $\times 0.5-0.7 \mathrm{~mm}$. Fruit a capsule, cylindrical, dehiscing into 4-valves, densely crisped, green or greenyellow, 24-40x1.0-1.5 mm. Seeds numerous, narrowly obovoid, papillose, comose, lacking endosperm, yellow-brown, 1.2-1.5x0.35-0.50 mm, coma hairs length 6-8 mm. (Plates 1-4). Pollens yellow, single (sometimes tetrads), triporate, oblate in equatorial view, triangular in polar view, medium according to [36], 2-3 thin threads project from pollens surface seen in polar view called viscin threads: acetolysis resistant threads arising from the exine ((Hesse, et al., 2009)), equatorial axis $40-42 \mu \mathrm{m}$, polar axis 28-31 $\mu \mathrm{m}$, numerous. (Plate 5). The leaf venation has the following characters: Actinodromous $1^{\circ}$ veins, acrodromous $2^{\circ}$ veins, Increasing toward base $2^{\circ}$ veins spacing, Random reticulate $3^{\circ}$ veins, Sinuous $3^{\circ}$ veins course, Opposite percurrent $4^{\circ}$ veins, Fimbrial-no teeth marginal ultimate veins, Unbranched linear and curved freely ending ultimate veins (Plate 6). Stomatal complex anomotetracytic, in both surfaces, more in adaxial, stoma elliptic, (7-9) $\mu \mathrm{m}$; guard cell kidney like, (14-16)x(3-4) $\mu \mathrm{m}$. (Plate 7).

Type: Described from Germany, nr. Leipzig.

Studied samples

MRO: ESUH/ Qandil mountain (north-east of Erbil), $1800 \mathrm{~m}$, 25.8.2016, A. Sardar, S. Al-Dabagh and K. Rasul 7451.

Environment \& Presence

Present as individuals in the region, on the rocky soils; altitude: 1800 m; flowering: August. Found in Qandil Mountain within Rowanduz district (MRO). (Figure 1). 


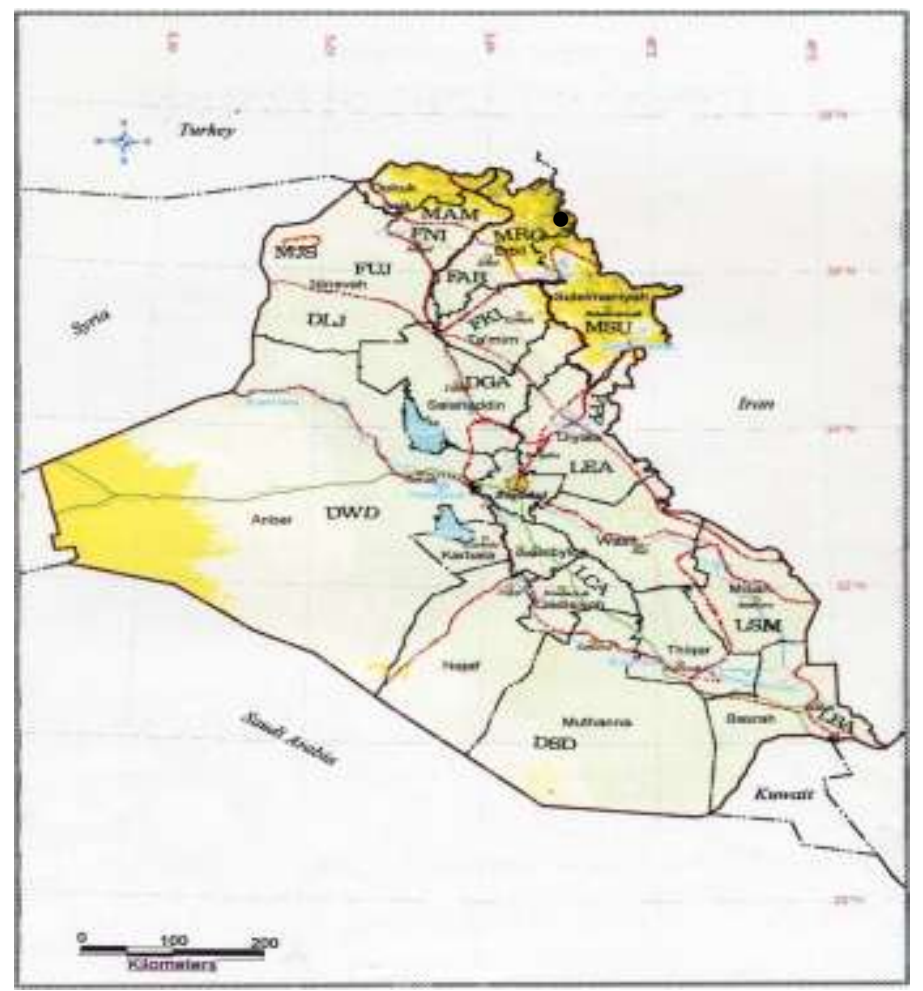

Fig (1): A map of Iraq shows the regions and districts depending on [37 and 38$] \bullet$ E. obscurum

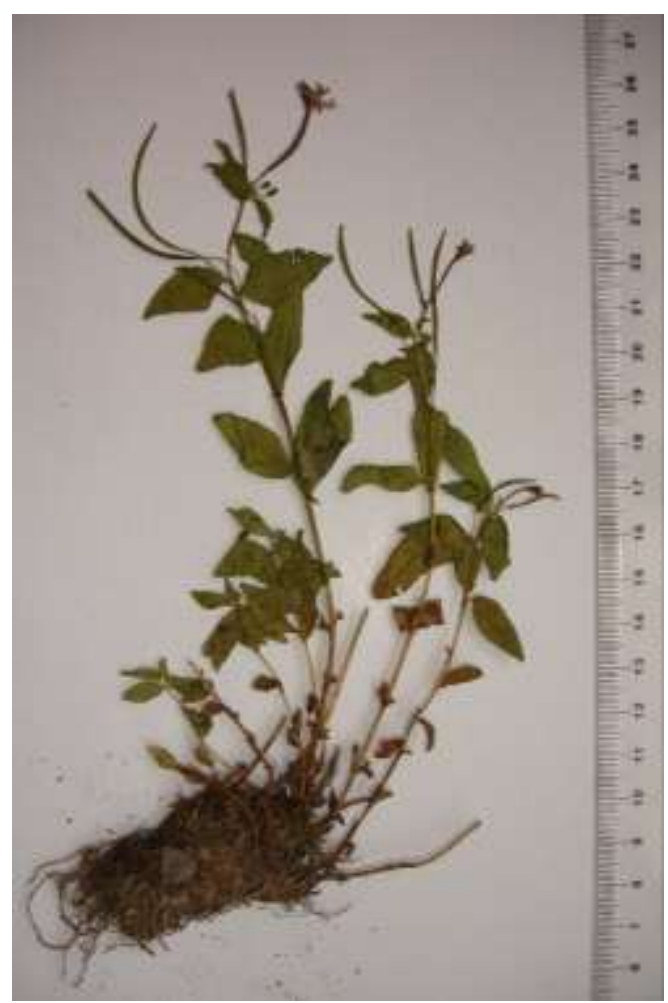

Plate (1): Photograph of E. obscurum

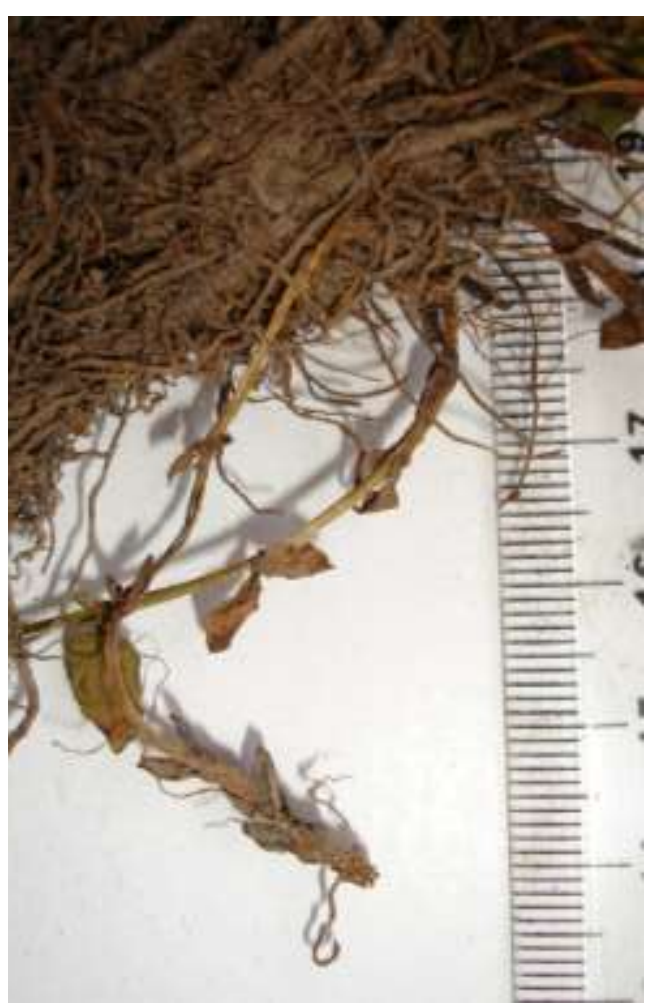

Plate (2): Stolon of E. obscurum
Life Sciences

Japan, Osaka
Abdullah Sh. Sardar, Aboothar Ha.Al-Edhari 


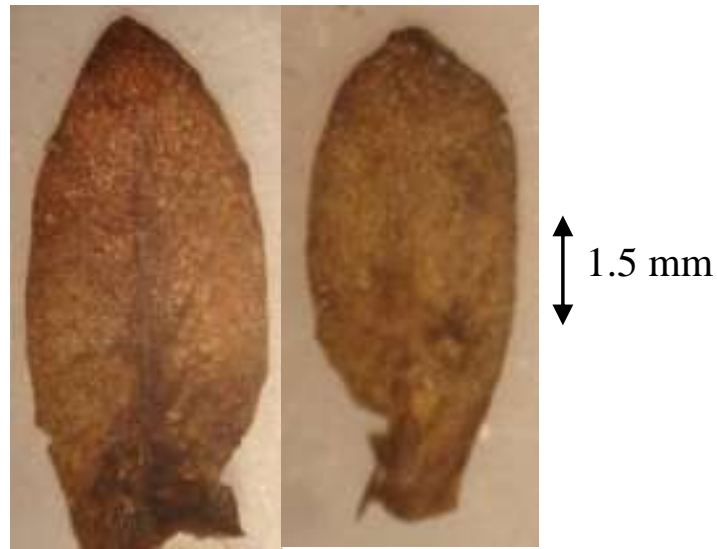

Basal leaves

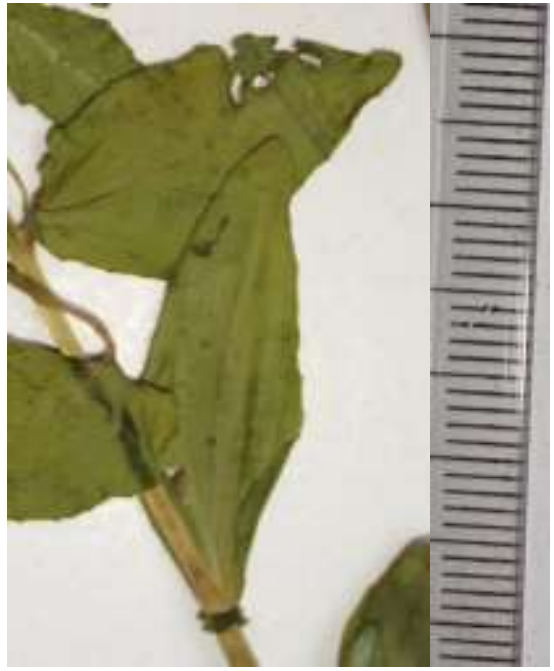

Upper cauline leaves

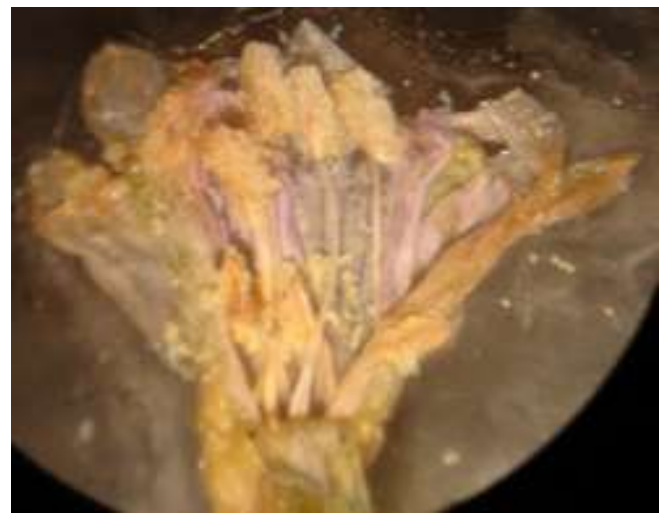

Opened corolla

Plate (3): Plant parts of E. obscurum

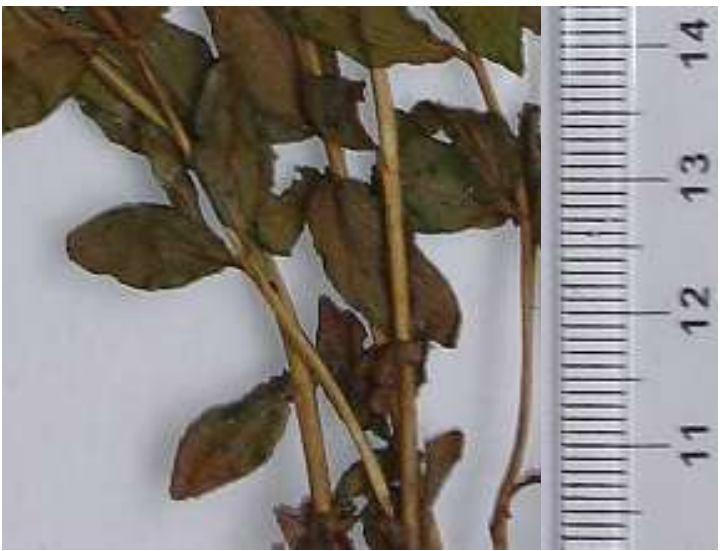

Lower cauline leaves

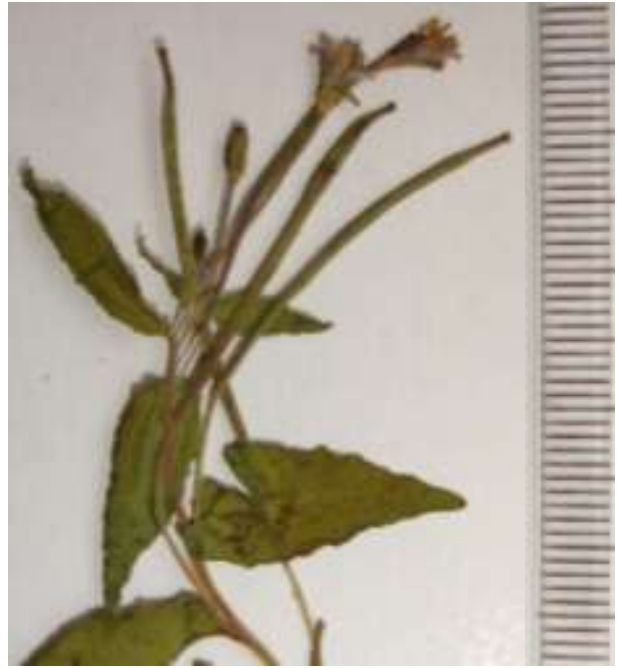

Bracts and inflorescence

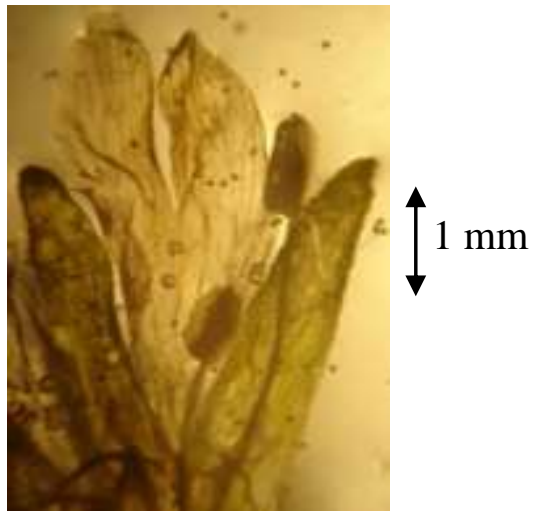

Sepals, petal and stamens $5 \mathrm{~mm}$

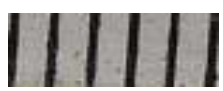

Life Sciences 


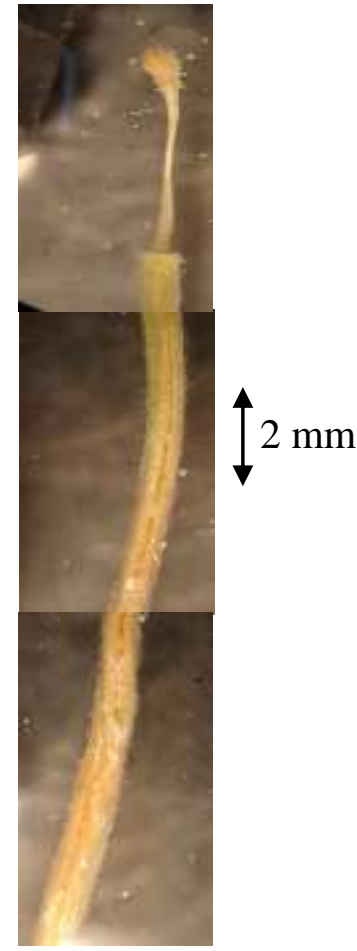

Pistil

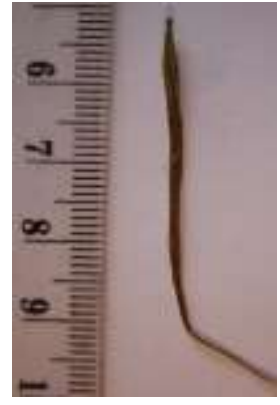

Fruit

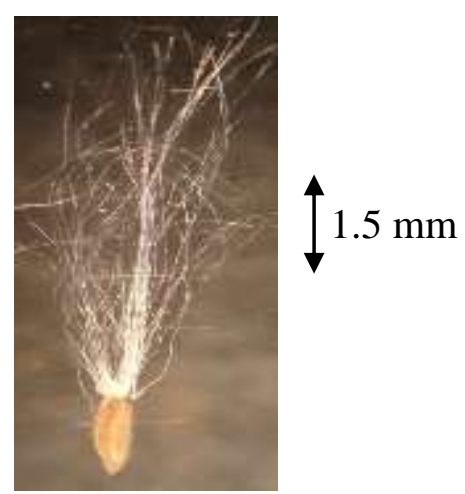

Seed

Plate (4): Pistil, fruit and seed of E. obscurum

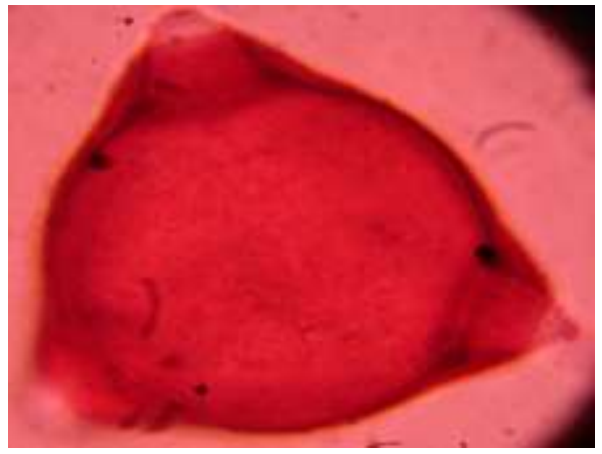

Polar view

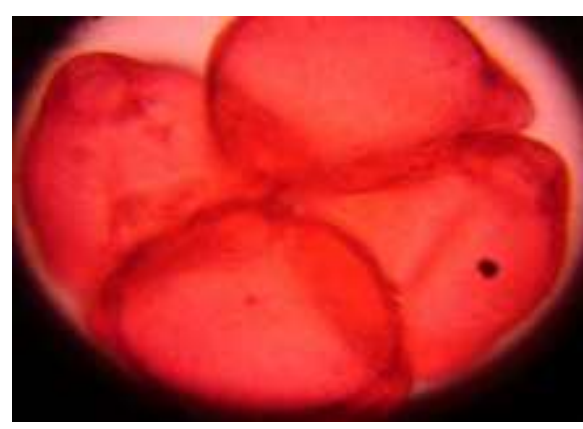

Tetrads

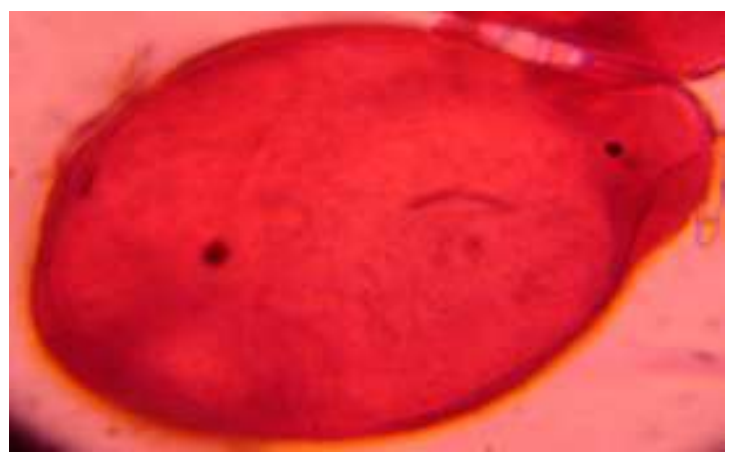

Equatorial view

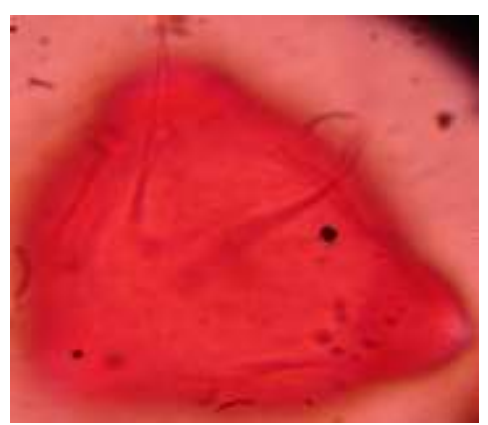

Vicin threads

Plate (5): Pollens of E. obscurum X100 (10 X100)

Life Sciences

Japan, Osaka
Abdullah Sh. Sardar, Aboothar Ha.Al-Edhari 
IFS 2,7

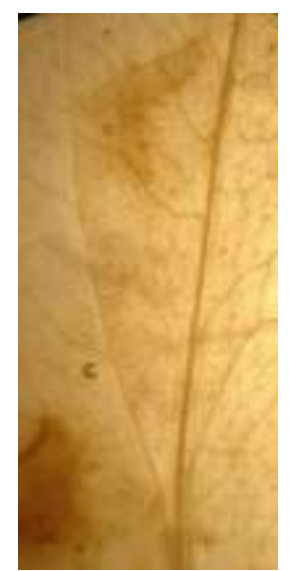

Acrodromous $2^{\circ}$ veins

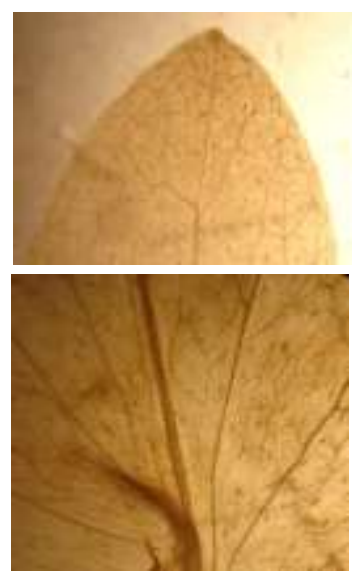

Increasing toward base $2^{\circ}$ veins spacing

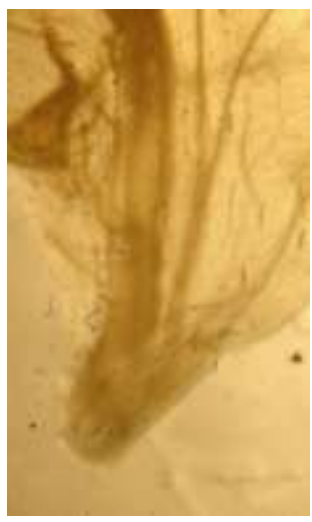

Actinodromous $1^{\circ}$ veins

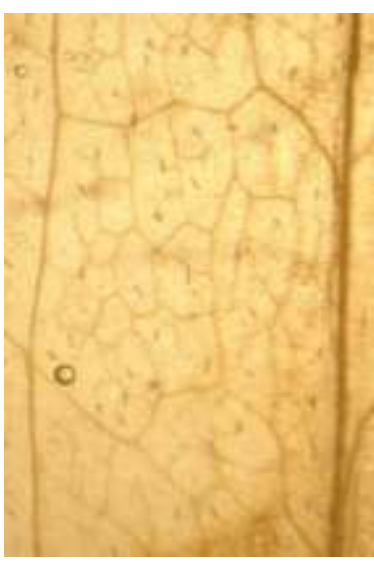

Random reticulate $3^{\circ}$ veins

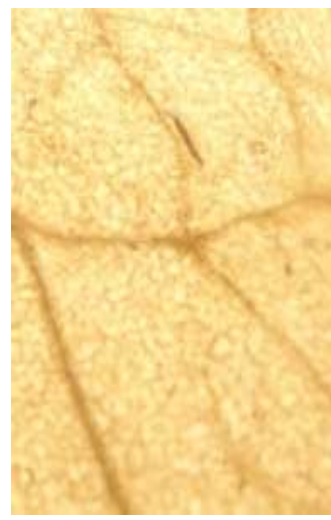

Opposite percurrent $4^{\mathrm{o}}$ veins www.journalofresearch.asia info@journalofresearch.asia

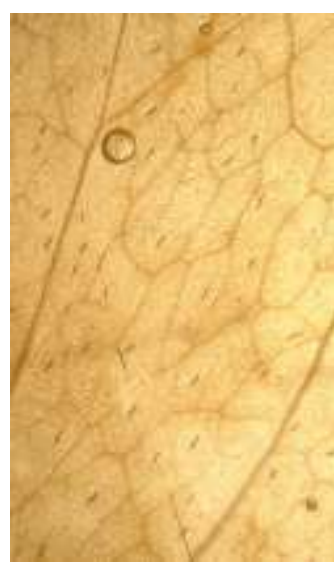

$\mathrm{X} 2$

$(10 \times 2)$

\section{X4 (10X4)}

\section{Sinuous $3^{\circ}$ veins} course

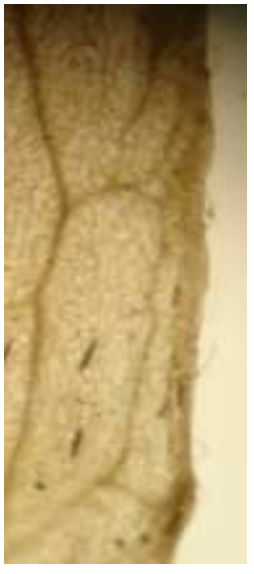

Fimbrial-no teeth marginal ultimate veins

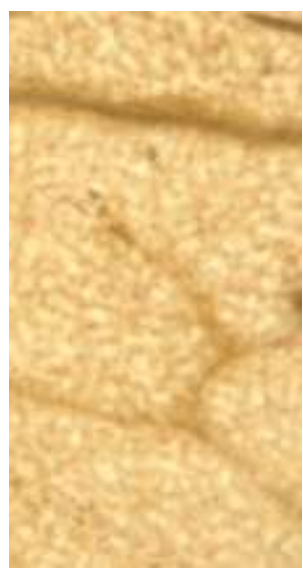

Unbranched linear freely ending ultimate veins

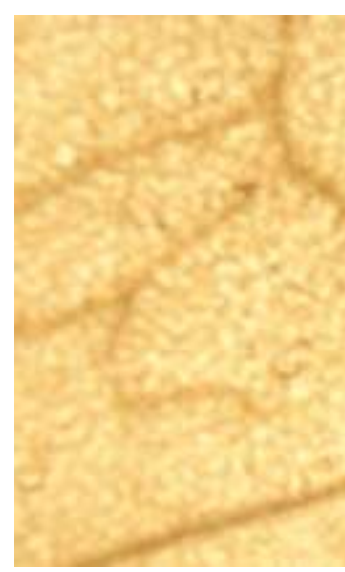

X4 (10X4)

Unbranched curved freely ending ultimate veins

Plate (6): Leaf venation of E. obscurum

Life Sciences

Japan, Osaka 


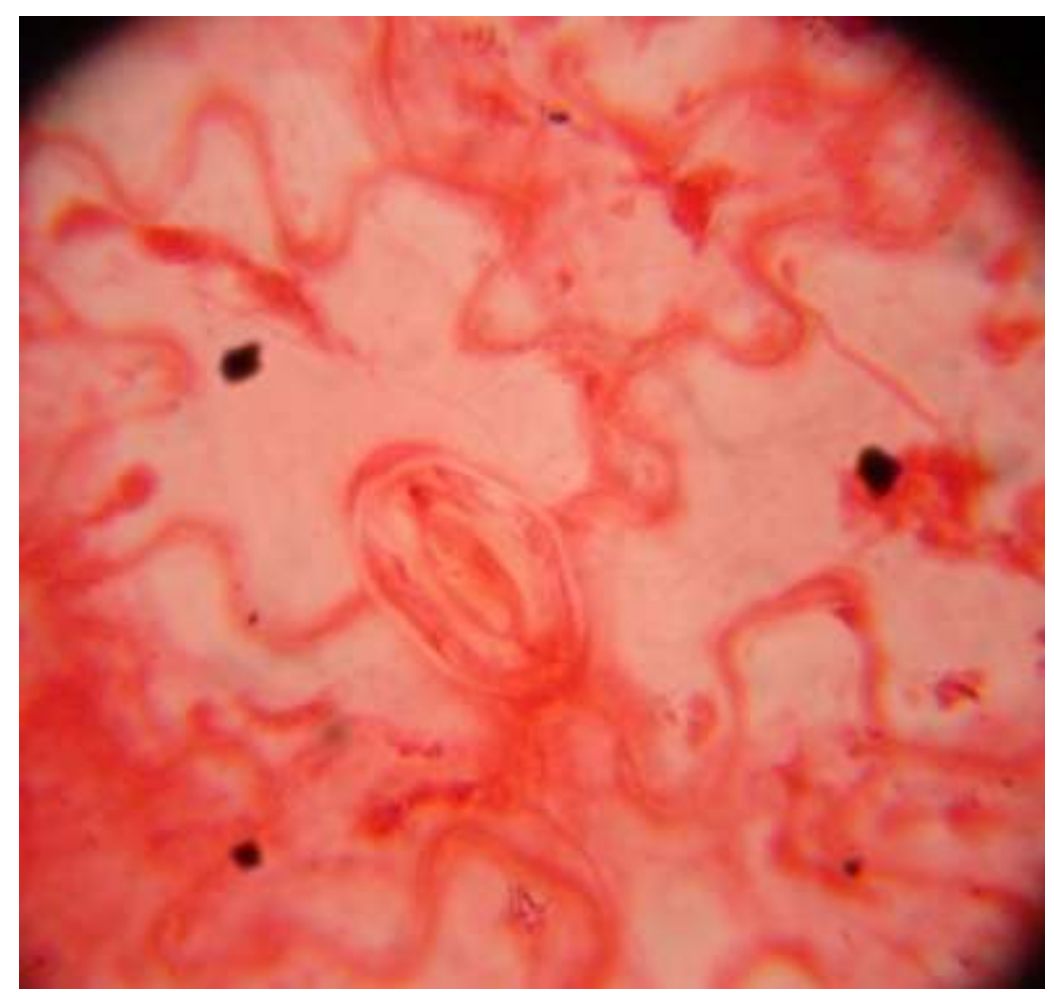

Plate (7): Stomatal complex of E. obscurum X100 (10X100) 


\section{4- Discussion}

The present work dealt with a new plant record of the genus Epilobium which is E. obscurum from Onagraceae family in Iraq, the study involved some aspects as the morphological characters and the environment. Within the literature review related to the genus Epilobium in Iraq, including the plant specimens of National Herbarium of Iraq (BAG), College of Science Herbarium, University of Salahaddin-Erbil, Iraq (ARB) and College of Education Herbarium, University of Salahaddin-Erbil, Iraq (ESUH), the researcher did not find any specimens belongs to E. obscurum, therefore it will be regarded as a new plant species to the Flora of Iraq (new record in Iraq) from Qandil mountain.

E. obscurum has some characters differ from the near species which is $E$. tetragonum L. that found in Iraq and has the following characteristics: elongate epigeal stolons; stem glabrous below, adpressed crisped hairy above, upper cauline leaves densely crisped margins and veins, Inflorescence with some glandular hairs, especially on the calyx and ovary; petals and capsules are smaller in length. Pollens were yellow, single (sometimes tetrads), triporate, oblate in equatorial view, triangular in polar view, medium numerous and 2-3 thin threads project from pollens surface seen in the polar view. Stomatal complex was anomotetyracytic (4 cells enclosing the guard cells in an irregular and variable pattern), found in both surfaces and more in adaxial. 


\section{References} USA: 259

1- Simpson, M. G. (2006). Plant Systematics. Elsevier Academic Press,

2- Al-Rawi, A. (1964). Wild plants of Iraq with their distribution. Ministry of Agriculture \& Irrigation, State board for agricultural \& water resources research, National Herbarium of Iraq, Baghdad: 85

3- Shishkin, B.K. (1949). Flora of the U.S.S.R., Vol.15. Izdatelstro Akademii Nauk SSSR, Moskva-Leningrad: 429-465

4- Migahid, A. M. (1978). Flora of Saudi Arabia. Vol. I, 2nd edition, Riyadh Univ. publ.: 374

5- Post, G. E. (1932). Flora of Syria, Palestine and Sinai. Vol. 1, American press, Beirut: 472-474 Raven, P. H. (1968). In: Flora Europaea.Vol.2. Cambridge Univ. Press: 308-311

6- Chamberlain, D. F. and Raven, P. H. (1972). In: Flora of Turkey. Vol. 4. Edinburgh at the University press: 183-196

7- Raven, P. H. (1968). In: Flora Europaea.Vol.2. Cambridge Univ. Press: 308-311

8- Raven, P. H. (19--). In: Flora Iranica. No.7, Akademische Druck-u. Verlagsanstalt, Graz-Austria: 3-18

9- Ghahreman, A. and Attar, F. (1999). Biodiversity of Plant Species in Iran. Central Herbarium, Tehran Univ., Tehran, Iran: 117-118

10- Rechinger, K. H. (1964). Flora of low land Iraq. Weinheim verlag von. J. Cramer, wein: 444

11- Guest, E. (1933). Notes on plants and plant products with their colloquial names in Iraq. Bull. No. 27. Government Press: 31

12- Zohary, M. (1946). The Flora of Iraq and its Phytogeographical Subdivisions. Iraq, Dep. Agri. Bull. No. 3: 108

13- Blakelock, R. A. (1948). The Rustum Herbarium, Iraq. Systematic List. Part 1., kew Bull, 3: 430

14- Ridda, T. J. and Daood, W. H. (1982). Geographical distribution of wild vascular plants of Iraq. National Herbarium of Iraq, Un publ.: 56-57

15- Ghazanfar, S. A. and Edmondson, J. R. (2013). In: Flora of Iraq. Vol.5, P.2, Ministry of Agriculture-Iraq, by Royal Botanic Gardens, Kew:12-16

16- Faris, Y. S. (1983). The Vascular Plants of Pira Magrun mountain. M. Sc. Thesis, Salahaddin University, Erbil, Iraq: 191 pp.

17- Fatah. H. U. (2003). The Vascular Plants of Haibat Sultan mountain and the Adjacent Areas. M. Sc. Thesis, University of Sulaimani, Sulaimaniya, Iraq. 
18- Ahmed, K. H. (2010). The Vascular Plants of Darband Gomaspan and the Adjacent Areas in Erbil Province. High Deploma Thesis, Salahaddin University, Erbil, Iraq: 38 pp.

19- Hameed, M. A. H. (2016). Vascular Plant Taxa of Hujran Basin-Erbil/ Iraq. M. Sc. Thesis, Kahramanmaraș Sütçü İmam University, Graduate School of Natural and Applied Sciences University, Kahramanmaraș, Turkey: 110 pp.

20- Darwesh, D. T. D. (2017). Plant Biodiversity and Ethnobotanical Properties of Various Plants in Choman (Erbil-Iraq). M. Sc. Thesis, Kahramanmaraș Sütçü İmam University, Graduate School of Natural and Applied Sciences University, Kahramanmaraș, Turkey: 130 pp.

21- Khalaf, M. K. (1980). The Vascular Plants of Jabal Sinjar. M. Sc. Thesis, Baghdad University, Baghdad, Iraq: 125

22- Ahmad, S. A. (2013). Vascular Plants of Hawraman Region in Kurdistan Iraq. Ph.D. Dessartation, University of Sulaimani, Sulaimaniya, Iraq: 169

23- Chakravarty, H. L. (1976). Plant Wealth of Iraq, A Dictionary of Economic Plants. Vol.1, Botany Directorate, Ministry of Agriculture \& Agrarian Reform, Baghdad-Iraq: 219-220

24- Al-Saadi, H. A. \& Al-Mayah, A. A. (1982). Aquatic Plants of Iraq. Univ. of Basrah press, Iraq: 90

25- Al-Musawi, A. H. and Majeed, I. A. (2013). New record species-from the family Euphorbiaceae in Iraq. Iraqi Journal of Science, 54(3), College of Science, University of Baghdad, Iraq: 536-546

26- Haloob, A. (2016). A New Record for the Flora of Iraq: Limonium Meyeri (Plumbaginaceae). Indian Journal of Plant Sciences, 5(1), An Open Access, Online International Journal: 8-10

http://www.cibtech.org/jps.htm

27- Sardar, A. Sh. (2017). A New Record of Saxifraga afghanica Aitch. \& Hemsl. (Saxifragaceae) in Iraq. Iraqi Journal of Science, 58(1B), College of Science, University of Baghdad, Iraq: 222-229

28- Al-Mayah, A.A. (1983). Taxonomy of Terminalia (Combretaceae). Ph.D. Dessartation, Univ. of Leicester, UK.

29- Hickey, L. J. (1999). Manual of Leaf Architecture, Morphological description and categorization of dicotyledonous and net-veined monocotyledonous angiosperms. Smithsonian Institution, Washington, US: 65

30- Harris, J. G. \& Harris, M. W. (2001). Plant Identification Terminology, An Illustrated Glossary. 2nd edition, Spring Lake Publishing, Spring Lake, Utah, United States: 206 pp

Life Sciences 
31- Hesse, M., Halbritter, H., Zetter, R., Weber, M., Buchner, R., Frosch - Radivo, A. and Ulrich, S. (2009). Pollen Terminology, An illustrated handbook. Springer - Verlag/Wien, Austria: 219

32- Agashe, S. N. and Caulton, E. (2009). Pollen and Spores, Applications with Special Emphasis on Aerobiology and Allergy. Science Publishers, Enfield, NH, USA: 400 pp.

33- Sardar, A. Sh. (2013). Systematic Study of Crassulaceae DC. Family in Kurdistan Region - Iraq. Ph. D. Dessartation, University of Salahaddin, Erbil, Iraq: $276 \mathrm{pp}$.

34- Metcalfe, C. R. \& Chalk, L. (1950). Anatomy of the Dicotyledons, Leaves, Stem, and Wood in Relation to Taxonomy with Notes on Economic Uses. Vol. 1, Oxford, at the Clarendon press: 664.

35- Watson, L. and Dallwits, M. J. (1991). The Families of Flowering Plants, Descriptions, Illustrations, Identification, and Information Retrieval.

http:/ biodiversity.uno.edu/delta/'

36- Erdtman, G. (1971). Pollen Morphology and Plant Taxonomy, Angiosperms. Hafner publishing company, New York:18

37- Guest, E. (1966). Flora of Iraq. Vol. 1, Ministry of Agriculture of Iraq: 213 pp.

38- FAO., (2002). Yearly report of Food and Agriculture Organization of the United Nations. Agricultural production department, Erbil-Iraq. 